\title{
'Gates Pure and Shining and Serene': Mutual Gazing as an Amatory Motif in Western Literature and Art
}

ROBERT BALDWIN

Despite the many literary studies on the theme of amorous gazing, ${ }^{1}$ no historian of literature or art has ever discussed the motif of lovers gazing mutually into each other's eyes. Literary love gazing is for the most part one way, either a dart-like glance from the beloved which penetrates the lover's eyes and wounds his heart, ${ }^{2}$ or an equally devastating glance of the lover at the physical beauty of the beloved. As love's metaphors of darts, arrows, wounds and sickness imply, the lover is too overwhelmed to 'fire' back amorous glances of his own. Mutuality then is less important to most literary love gazing than metaphors of one-sided devastation and surrender before the irresistible power of erotic desire.

The present study will explore the motif of mutal gazing in love themes, with a focus on Renaissance works and their earlier sources. As we shall see, these works represent a love which is essentially reciprocal and non-violent, a love often conjugal and free from the devastation of eros so important for the more common literary motif of one way glances.

That love starts from sight and is intimately connected to it is already a commonplace in ancient love poetry. ${ }^{3}$ Despite this, not many texts speak of mutual gazing. Ovid's Amores mentions an ocular 'discourse of my eyes' which 'secretly receive and send forth, these signals of our love.'4 At the same time, one of Propertius' Cynthia poems reads, 'While fate allows, let us feed our eyes with love. A long night comes and day will not return. ${ }^{5}$ Here the eyes sum up all that is physical and satiable before the long night of death. The same mutual and erotic ocular feeding appears at least implicitly in the more famous opening lines of Lucretius' De Rerum Natura (The Nature of Things), where Mars lies in the lap of Venus. ${ }^{6}$ It 
was this passage which inspired so many Renaissance and Baroque pictures of various lap-lying lovers gazing into each other's eyes. ${ }^{7}$

By far the most influential text, either directly or indirectly, was Plato's Phaedrus. There, we find a discussion of amorous and spiritual sight as a stream of love particles radiating out from the eyes of the lover to those of the beloved, reflecting back to the lover again. 'Wherefore as she [the man's soul] gazes upon the boy's beauty, she admits a flood of particles streaming therefrom - that is why we speak of a "flood of passion" ' 8 According to Plato, this

flood of passion, pours in upon the lover, and part of it is absorbed within him, but when he can contain no more, the rest flows away outside him: and as a breath of wind or an echo, rebounding from a smooth hard surface, goes back to its place of origin, even so the stream of beauty turns back and reenters the eyes of the fair beloved . . . whereby the soul of the beloved in its turn is filled with love. ${ }^{9}$

Plato's lover at this point is 'like one who has caught a disease of the eye from another, he cannot account for it, not realizing that his lover is as it were a mirror in which he beholds himself.'10

Closely derived from this Platonic model was a fourth-century (A.D.) romance by the Greek poet Achilles Tatius. In it, the lover Clinias asserts that the sight of his beloved is more pleasurable than the joys of lovemaking.

And why so? Because the eyes, when encountering each other, receive bodily impressions, as in a looking glass, and the reflection of beauty glancing into the soul, begets union, even in separation . . . the eye is a wondrous vehicle of love and constant intercourse is most influential in begetting kindly feelings. ${ }^{11}$

Later, in another episode, we read that

lovers find their chief delight in gazing upon the beloved; ... the pleasure conceived by the eyes flows through them into the mind, bears along with it the image of the beloved and impresses its form upon the mirror of the soul. ${ }^{12}$

The notion of the beloved's eyes, face, or soul as a mirror derives from Plato, as we have seen, and becomes a common topic in troubador poetry. ${ }^{13}$ One well-known example is Gottfried von Strassburg's thirteenthcentury romance, Tristan and Isolde, in which Isolde's eyes are described as follows: 'There was scarce a pair of eyes to whom her two mirrors were not a marvel and a delight. ${ }^{14}$ Later, the two lovers drink the love potion and 'became one and unified now who had previously been 
two and disparate; the two were no longer at odds with one another . . . they were so joined in love that each was clearer than a looking-glass to the other. They had one heart between them.' ${ }^{15}$

If this theme of mirroring eyes and lovers as mirrors also found positive visual expression in scenes combining unicorns and mirror-holding virgins, a popular late medieval allegory of love, ${ }^{16}$ it also appeared as an object of ridicule in Renaissance images mocking the outmoded and morally suspect world of courtly romance. Such criticism is clear in an anonymous fifteenth-century German woodcut where two mutually gazing lovers sit beneath a monkey gazing into a mirror. ${ }^{17}$ The young man here is being made an ape of, as the inscription reads. The ocular rapture he experiences blinds him to the thieving hand of his beloved (presumably a prostitute) who picks his pocket. Another fifteenth-century German print, this by the Master E.S., makes a similar point with its male dressed as a fool, his moronic grinning face reflected in a mirror held by a prostitute. Lust obviously makes fools of all humanity, especially those who couch their base desire in the lofty forms and metaphors of courtly love. ${ }^{18}$

If these texts and images invoke the Platonic and courtly conceit of eyes as mirrors reflecting the lover's soul, they rarely focus in on the theme of interlocking vision so important for later authors and artists. Important in this regard is one of the most famous and influential of all medieval romances, Guido delle Colonne's Historia Destructionis Troiae, written in 1287. ${ }^{19}$ Guido's description of Paris' first encounter with Helen is a classic of mutual gazing.

\begin{abstract}
With the greatest eagerness Paris placed himself close to Helen, without disregarding the limits of modesty, and while he was fixing his gaze upon her eyes, Helen returned his glance as he watched with the answering reply of her glances.... Because she was completely consumed by a desire to look at Paris, she did not turn her eyes away to watch anything else. When Paris saw her caressing him with her eyes, he rejoiced that his eyebeams were mingled with Helen's eyebeams. Thus through reciprocal and pleasing glances they revealed to each other that they agreed together in the violence of their mutual love ...20
\end{abstract}

If this text shows the erotic power of glances and gazing in the middle ages, ${ }^{21}$ it also speaks of the ocular ability to communicate thoughts and to signal agreement, especially of an amorous kind. A more chaste and faithful love is described in ocular metaphors in Hildegard of Bingen who distinguished between ravenous, violent and erotic gazing and a gentler sort expressing a virtuous accord between the sexes. Her men most apt for love "can have an honorable and fruitful association with women, but they can also withhold, and regard them with looks of affection and 
moderation. For the eyes of such men come admirably into accord [symphonizant] with those women, whereas the eyes of other men are [fixed] on them like arrows.' ${ }^{22}$ She goes on in the next few lines to speak of such masculine love as a 'bridled prudence,' ['temperata prudentia'] a clear reference to the controlling of passion and appetite which was essential to all noble and sacred love. Hildegard's sense of a bridled and spiritual male gaze harmonizing with female eyes echoes typical medieval ethical doctrines of restraint, moderation, and prudence as cardinal virtues of higher love. ${ }^{23}$ Her notion of tempered amorous passion may even have drawn on the Platonic allegory, found in the Phaedrus, of the charioteer controlling his horses - the basis for many medieval allegories of the mind controlling the passions, reason bridling the senses. ${ }^{24}$

Also celebrating chaste and faithful love in ocular metaphors is Chrétien de Troyes' Cligés. Describing the first encounter of the hero Cligés with the fair maiden, Fenice, Chrétien brings us closer to the kind of conjugal gazing seen later in Renaissance portraits.

Cligés, under the sway of love, let his eyes rest on her covertly ... Blithly he looks upon the maid, but does not note that she repays him in kind. Not flattering him but in sincere love, she gives him her eyes, and takes back his ... she knows nothing except that he is fair, and that, if she is ever to love any one for beauty's sake, she need not seek elsewhere to bestow her heart. She handed over to him the possession of her eyes and heart, and he pledged his in turn to her. ${ }^{25}$

The above quotations should make clear that the Platonic idea of sight beaming back and forth from mirror-like eyes and carrying the soul (or heart) with it was well known to medieval literature. Along with it came the notion of sight as the most spiritual of the five senses, an idea found in many other ancient authors as well. There was, as is well known, a traditional ranking of the senses from noble sight and hearing down to ignoble smell and taste and finally bestial touch. ${ }^{26}$ An interesting examples of this comes from a thirteenth-century poem, the Romance of Flamenca.

When two lovers, true and sincere.

Look in each other's eyes in clear

And perfect love, why then I think

Such joy into each heart doth sink

That the pure bliss it doth impart

Will heal and nourish every heart.

The eyes, through which travels and passes

That joy which in the heart amasses,

So loyal are they that withhold

For their use nothing that they behold,

Whereas the mouth, of every kiss

Retains some portion of the bliss 
For its own use, thus savoring

It ere the heart gets anything

Those others who with careless ease

Kiss, and then wander as they please

In matters far more intimate,

Pause not for things so delicate.

Yet some men rightly don't despise

The rapture kindled in the eyes

Which they forget not nor dismiss

Even for touch, embrace, or kiss

They do not know exactly what

It is, but they are soundly taught

By Reason, Grace, and Mind to feel

That kisses are the faithful seal

Of that joy which true love creates,

Of which the eyes become the gates,

Gates pure and shining and serene. ${ }^{27}$

Here we have one of the clearest examples of spiritual or rational mutual gazing between lovers, a love refined above the baser, less 'serene' senses of taste and touch, kisses and embraces. This of course is the kind of love ideally enjoyed by husband and wife, the chaste love of such virgin couples as Henry II and Cunegunde or the legendary Saint Cecilia and Valerian. ${ }^{28}$ It is also the Neoplatonic love celebrated by Ficino in his Commentary on Plato's Symposium (c. 1475) where the medieval hierarchy of the five senses is discussed with respect to love. ${ }^{29}$ Closer to our theme are Ficino's comments on amorous sight and the beloved's beauty in which he uses the familiar Platonic and courtly metaphor of mirroring.

A lover imprints a likeness of the loved one upon his soul, and so the soul of the lover becomes a mirror in which is reflected the image of the loved one. Thereupon, when the lover recognizes himself in the lover, he is forced to love him. ${ }^{30}$

Although there is no mention of intertwined eyebeams, it is implied in the context of love gazing and is made explicit in Castiglione's later, popularized discussion in the Cortegiano (1527), clearly based on Ficino. I quote from Hoby's English translation of 1561, one of numerous translations and editions from the time. As guides in love,

the eyes shoote, and like sorcerers bewitch, and especially when by a right line they send their glistering beames into the eyes of the wight beloved, at the time when they do the like, because the spirits meete together, and in that encounter the one taketh the other's nature and qualitie. ${ }^{31}$ 


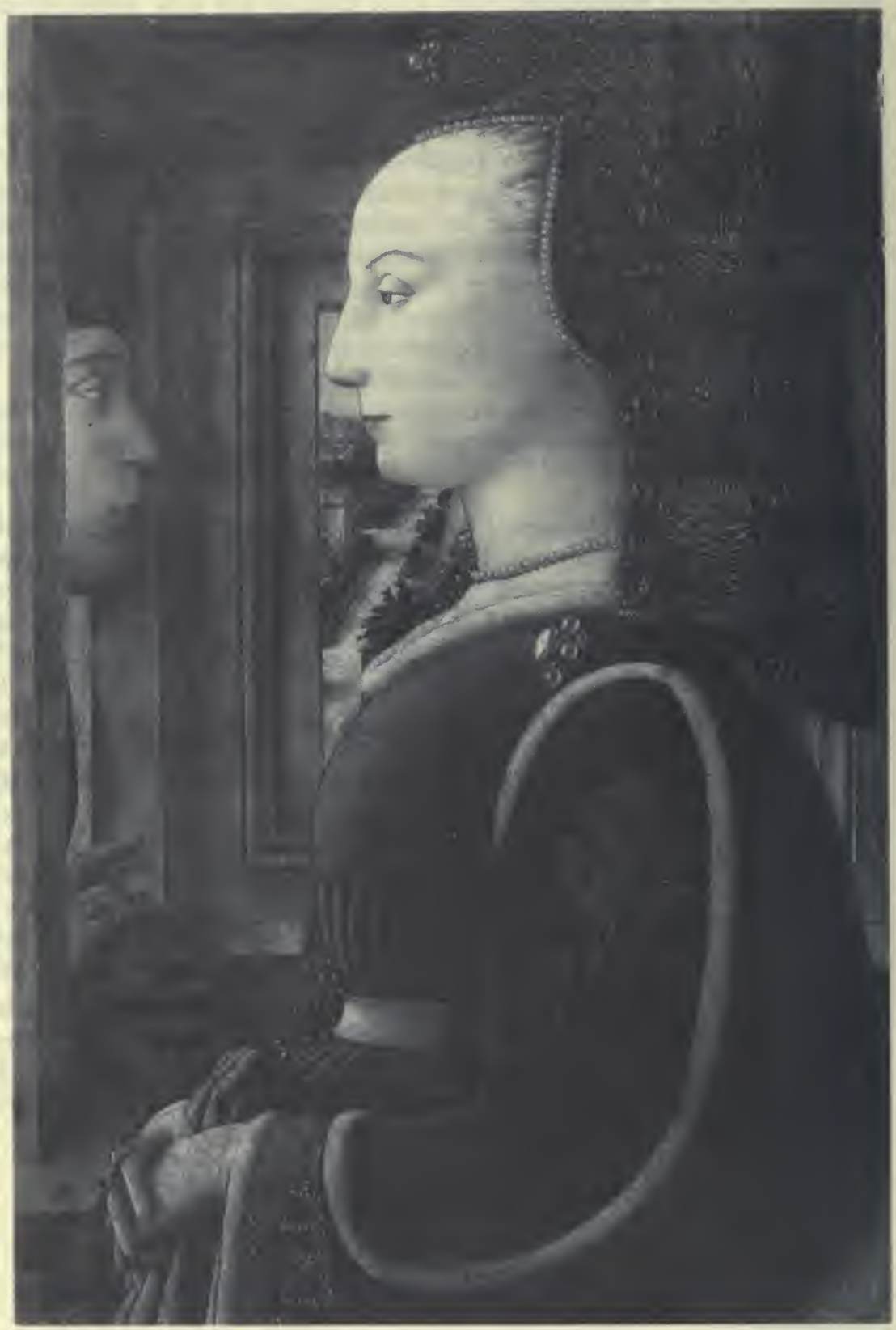

Fig. 1: Fra Filippo Lippi, Portrait of a Man and a Woman at a Casement, Metropolitan Museum of Art, New York 
Renaissance et Réforme / 29

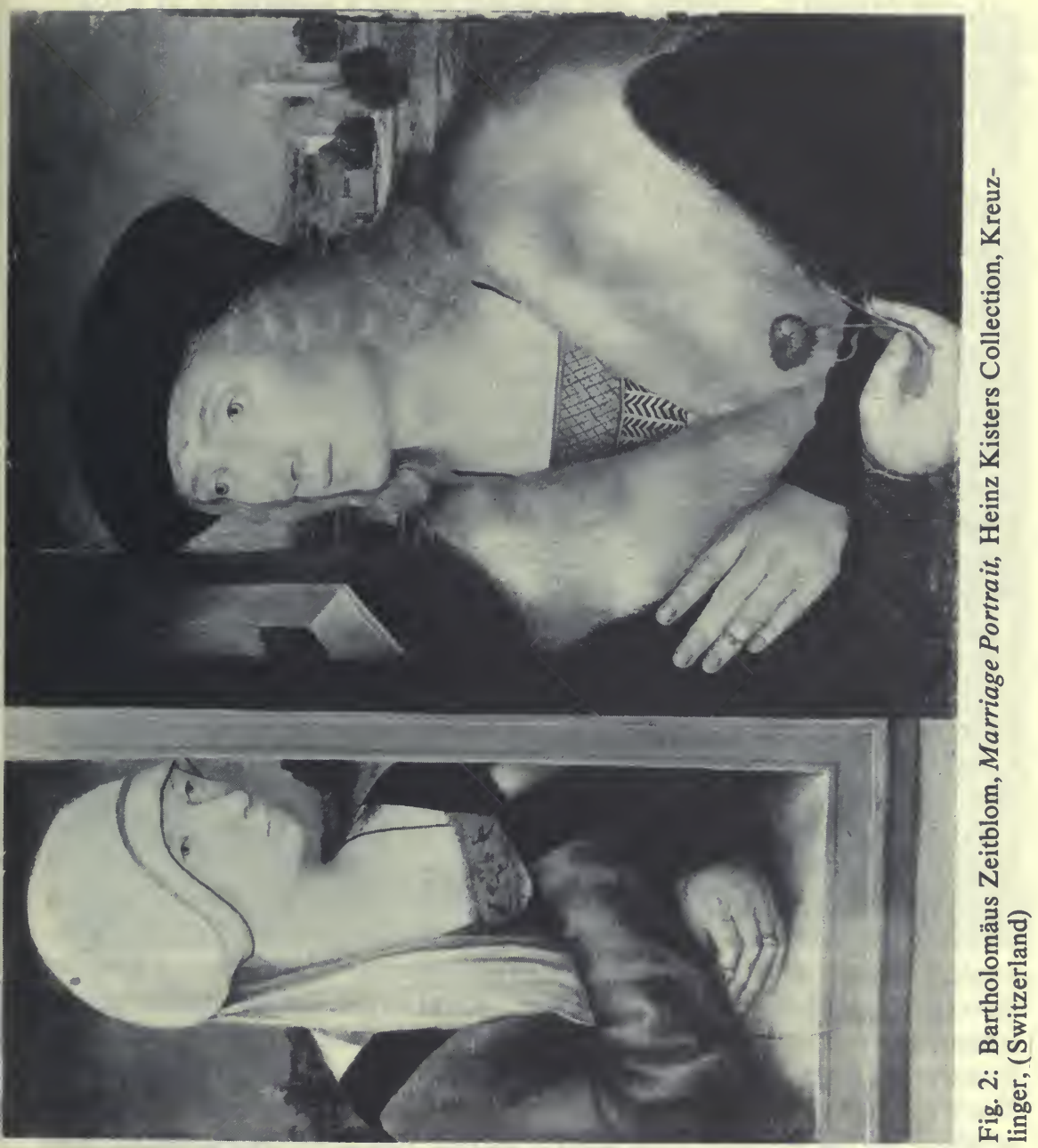


It was through Castiglione and possibly Bruno's Candelaio of $1582^{32}$ that the theme of amorous souls linked by reciprocal gazing became so common in Elizabethan poetry, ${ }^{33}$ finding its greatest expression in Donne's The Extasie. ${ }^{34}$

\section{$* * *$}

This tradition of spiritual, mutual gazing in which hearts could intertwine along eye-beams seems to lie behind two hitherto perplexing Renaissance conjugal portraits: Fra Filippo Lippi's painting of around 1445 in the Metropolitan Museum ${ }^{35}$ (fig. 1) and Bartholomäus Zeitblom's picture of c. 1505 in the Heinz Kisters collection in Kreuzlingen, Switzerland (fig. 2) ${ }^{36}$ Although neither works shows the man and woman in the same plane with eyes that convincingly meet, this seems more a question of difficulties in spatial handling than aesthetic intention. If the husbands and wives are not meant to be looking at each other, what could these strange compositions possibly mean? When we remember that the conjugal bond was one of souls uniting in reciprocal fidelity, (even if bodies were expected to follow suit), the window gazing motif emerges as a perfect device to bring out the spiritual nature of matrimonial union. For the wall between man and wife prohibited any physical embracing and other less sacred exchanges. This value to the window and to the gazing motif would have only been enhanced by drawing on the familiar metaphor of the eye as the soul's window, ${ }^{37}$ the "windows' of sacramental love whereby souls mingled in perfect harmony.

Looking a little deeper at these two works, we find a much richer background to the window-gazing motif in its echoes of Canticles 2:9: 'Behold he standeth behind our wall, looking through the windows, looking through the lattices... ${ }^{38}$ A number of late medieval and fifteenthcentury scenes of the Annunciation even show God the spouse looking through the window at Mary, ${ }^{39}$ his mystical bride. Other medieval and Renaissance illustrations of Canticles 2:9, including a thirteenth-century illustration from a Bible moralisée ${ }^{40}$ (fig. 3) and a drawing by Marten de Vos (fig. 4), ${ }^{41}$ show a mutually gazing groom and bride. Presumably, this window gazing in Lippi, Zeitbloom, and de Vos drew on a passage from one of the most famous of Canticles commentaries, the twelfth-century sermons of Gilbert of Hoyland which continued those of Bernard of Clairvaux left incomplete at his death. Copied along with Bernard's sermons in numerous medieval manuscripts, Gilbert's sermons were also printed in at least fifteen editions by 1560 . In Canticles 4:9: 'Thou hast wounded my heart with one of thy eyes,' he writes,

Do not hesitate, $\mathrm{O}$ bride, to aim such weapons at your Spouse. Use devout glances as darts ... pierce him with wound after wound. Happy are you if your 


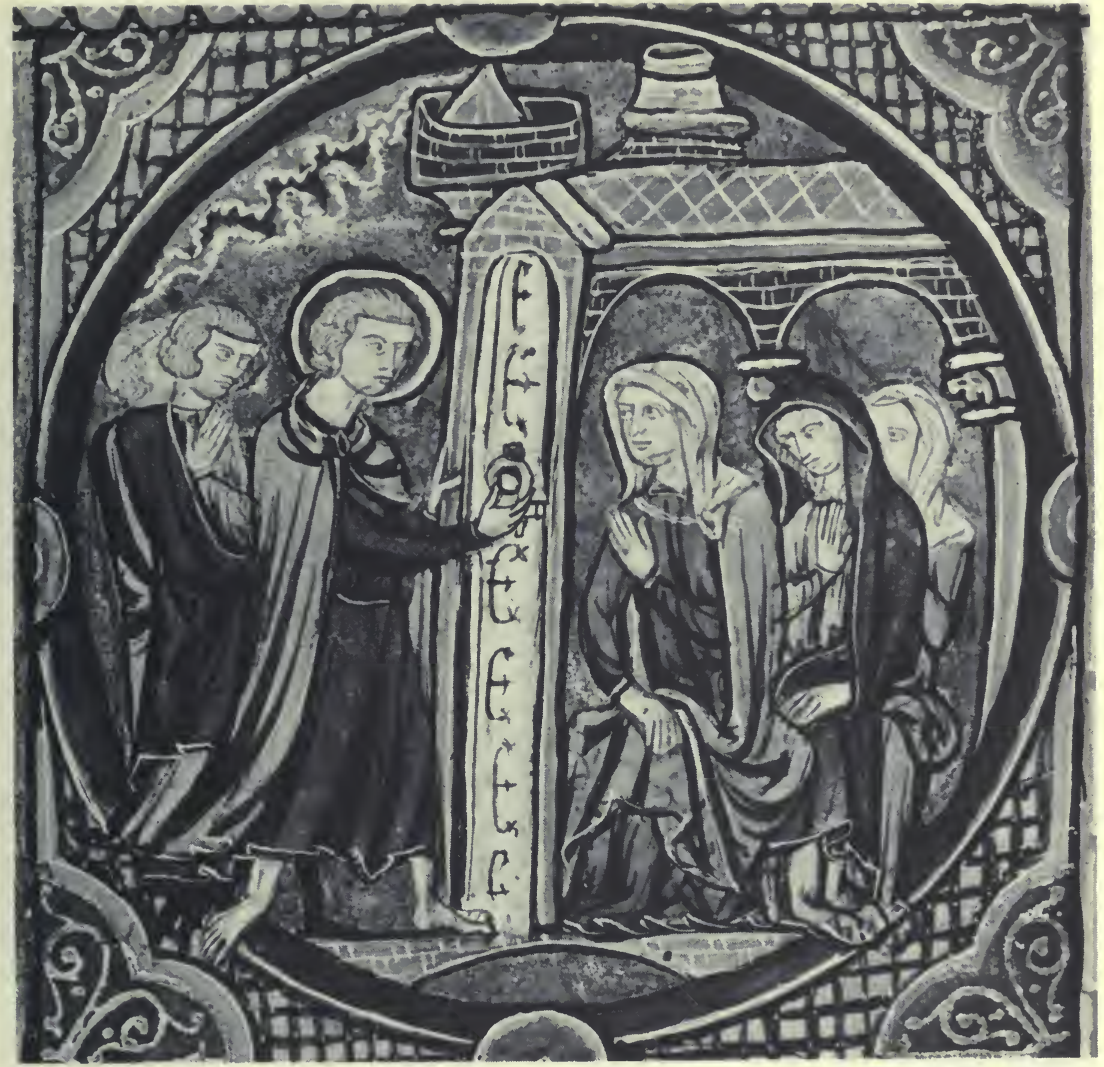

Fig. 3: Bible moralisée, illustration to Song of Songs 2:9, Bibliothéque Nationale, Paris.

arrows are fixed in him ... if your eye is fixed upon him unwearingly . . aim at him the arrows of a pure gaze ... For no sound health is there where there are no wounds inflicted by the loving gaze of Christ. One gaze challenges another; therefore try to wound him with your view from afar. Let your eyes be ever upon the Lord, that he many be captured in the glances of your love. ${ }^{42}$

In John of Ford's sermons on the Canticles, which in turn completed the verses left unexplained by Gilbert, we read,

To behold the majesty of God, the wisdom of God, the goodness of God, they had no need of relying on many steps or immersing themselves in the complications of disputed points. They had simply to return the gaze of their 


\section{2 / Renaissance and Reformation}

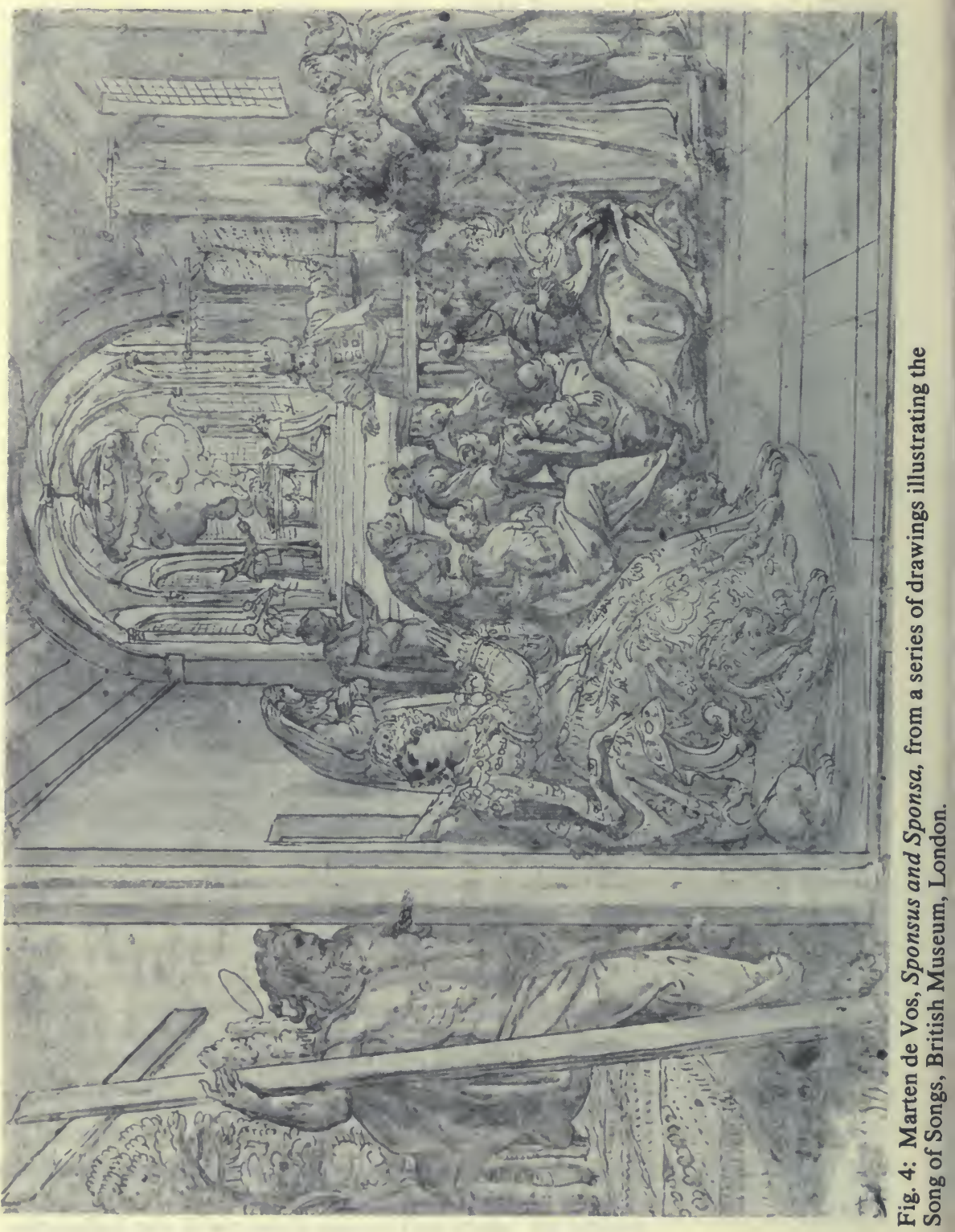


beloved, standing behind our wall, and gazing on us through the window of our senses. Only the thickness of one wall, only one step, separated them from the ineffable contemplation of the eternal light which is in heaven. ${ }^{43}$

Earlier in the same sermon, John of Ford develops at some length the eschatalogical nature of the soul's mutual gazing with God. Such gazing in the next world, of course, draws on Paul's 'face to face' sight from 1 Corinthians 13:12. We see such eschatalogical seeing in a twelfth-century illustration of the Canticles which depicts Christ and his triumphant bride enthroned beside Him (fig. 5) ${ }^{44}$ At the right, through the window, past the wall of sin and flesh, is Christ's other bride, the human soul, here labelled 'saved humanity,' and clearly waiting for the 'face to face' sight enjoyed by Virgin-Ecclesia. In a more general context, mutual gazing could evoke the reciprocal love and union between God and the human soul. Such ocular metaphors appear as a leitmotif in Nicolas of Cusa's fifteenth-century mystical treatise De Visione Dei (The Vision of God).

When I look unto thee alone with all my attention, nor ever turn aside the eyes of my mind, because Thou dost enfold me with They constant regard. ${ }^{45}$

In a chapter entitled 'On Seeing Face to Face', Nicolas writes, 'O Lord my God, the longer I look upon Thy face, the more keenly dost Thou seem to turn the glance of Thine eyes upon me. ${ }^{46}$

With this tradition of window motifs and mutual gazing, we can see in a new light the gazing which goes on between Mary and Christ, bride and groom, in so many Renaissance and Baroque paintings. Francesco Traini's Princeton Madonna and Child (c. 1345) for example, combines mutual gazing with the coral amulet hanging around Christ's neck, a common apotropaic device of the time used to protect babies from the evil eye. ${ }^{47}$ Clearly, he is enjoying the good eye here, the eye of the bride, of the church, of the human soul pledged to him. ${ }^{48}$ John of Ford even speaks of such mutual conjugal gazing between the Virgin and Child. ${ }^{49}$ If scenes of the Virgin and Child seem to employ Canticles gazing, so do images of the Lamentation which stress the open eyes of Mary next to the closed eyes of the dead Christ, eyes which cannot now reciprocate her love. Though many works could be cited, Bellini's Brera Lamentation is certainly one of the most poignant examples. Another variation is the kind of mutal gazing which often goes on between Christ and the eldest magus in scenes of the 'Adoration of the Magi.'

This, then, is the context for understanding Lippi's and Zeitblom's marriage portraits with their mutual gazing through the window. The reference to the Canticles defines their love as sacramental, as based on the union between Christ and his Church, mystical groom and bride. The basis 


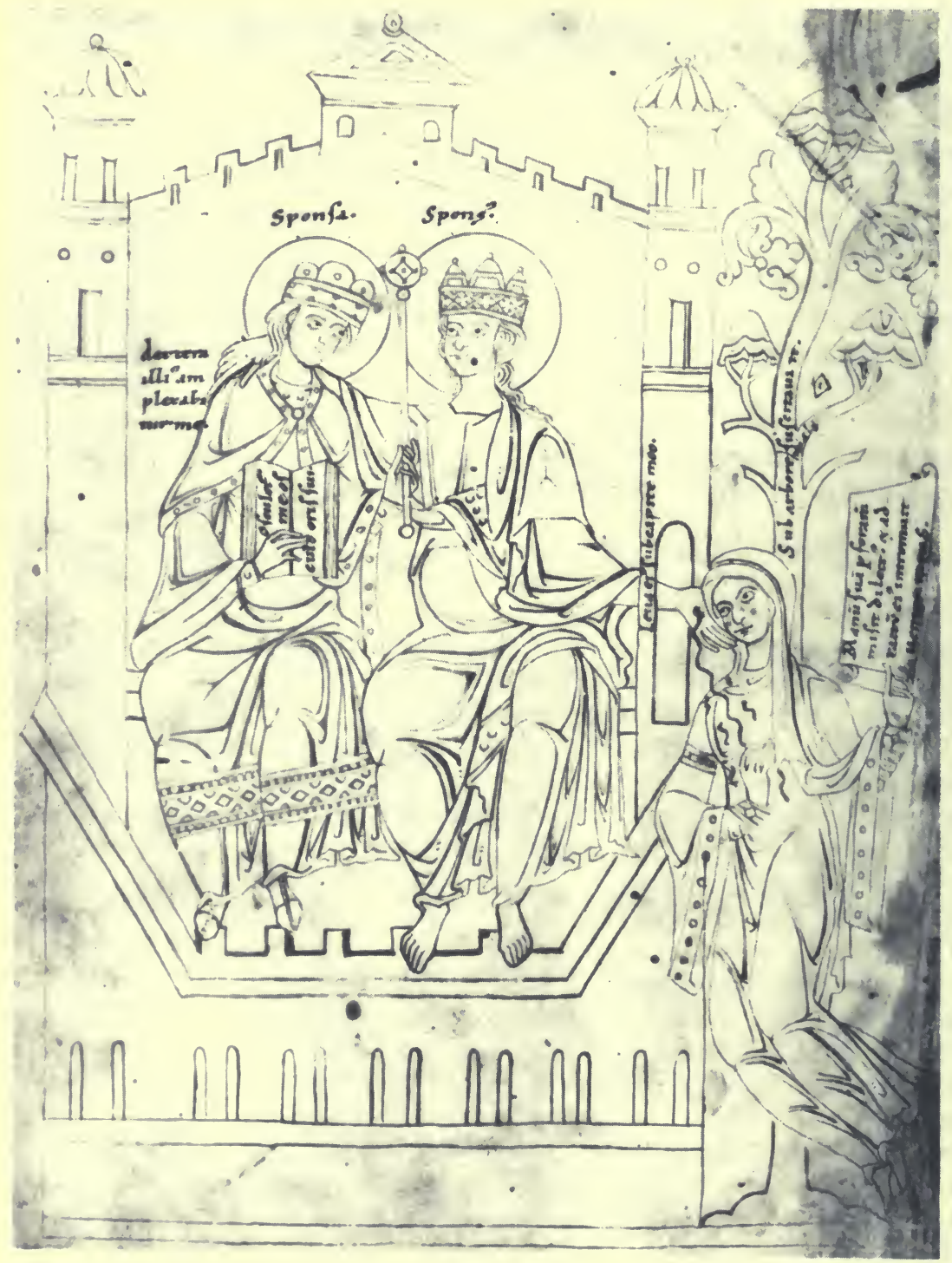

Fig. 5: Sponsus and Sponsa, frontispiece to a 12-th century, South German ms. of Honorius Augustodunensis, Bayerische Staatsbibliotek, Ms. lat. 4450, fol. Iv. 
of this sacramental connection of course is Ephesians 5:25, 'Husbands, love your wives, as Christ also loved the church and gave himself for it.' In this sense, Lippi's painting parallels Jan van Eyck's contemporary Arnolfini Wedding which also clearly establishes the mystical marriage of Christ to the Church as the basis for sacramental matrimony. In the Van Eyck, the Passion brings out the sacramental archetype which human marriage imitates; ${ }^{50}$ in the Lippi and the Zeitblom, the Canticles window effects this connection while pointing up the spiritual, mutual, and faithful aspect of conjugal love more generally.

With this understanding, it is now possible to understand what Ishrahel van Meckenem and his wife wanted to convey in his engraved self-portrait of around 1400 (fig. 6). Though scholars have noted Meckenem's general debt to Roman tomb reliefs, antique models with mutual gazing between husband and wife have not yet been cited. One of a number of such reliefs dates from the late first century B.C. and can be found in the Museo Nazionale delle Terme. (fig. 7) ${ }^{51}$ Such Roman precedents aside, Lippi, Zeitblom, and Meckenem took advantage of a posture which could express conjugal love in non-physical, tranquil, and mutual terms. This would also have suited the rules of decorum which generally prohibited public displays of physical love between husband and wife. In turn, the decorousness of mutual gazing made it ideal for the 'unmentionable' love Dürer explored in his woodcut, The Men's Bath (fig. 8). ${ }^{52}$ That love was his theme is clear enough from the carnation held by the right-hand gazer, this being an emblem of love in many Northern Renaissance conjugal portraits, including Zeitblom's. If Dürer's love here is erotic, as suggested by the very phallic water faucet, the juxtaposition of genitalia and mouth, and the ambiguous position of the left gazer's right hand, the emphasis on mutual gazing helps raise their affection to a more socially acceptable, Neoplatonic plane. Interesting is the motif of the 'amator exclusus,' the jealous lover who can only watch from the other side of the wall in the left rear. ${ }^{53}$ His gaze is ignored by the pair of lovers in the foreground in a similar way to that seen in Bosch's scene of amorous Envy from the Prado Seven Deadly Sins. ${ }^{54}$

Though sight and not touch was the acceptable way to express love in most fifteenth and early sixteenth-century Northern art, one would have expected examples of at least one kind of touching basic to conjugal iconography, the marriage rite of joined right hands or 'dextrarum iunction.' This gesture does appear in antique conjugal reliefs where eyes and hands thereby meet ${ }^{55}$ but it rarely appeared in later conjugal portraits. Either hands meet and eyes do not, or the reverse is seen. In sixteenth-century Venice, however, artists did not hesitate to combine interlocked eyes with kissing and the most erotic kind of touching. The art of Titian, Veronese, and other Venetian painters is full of erotic 
36 / Renaissance and Reformation

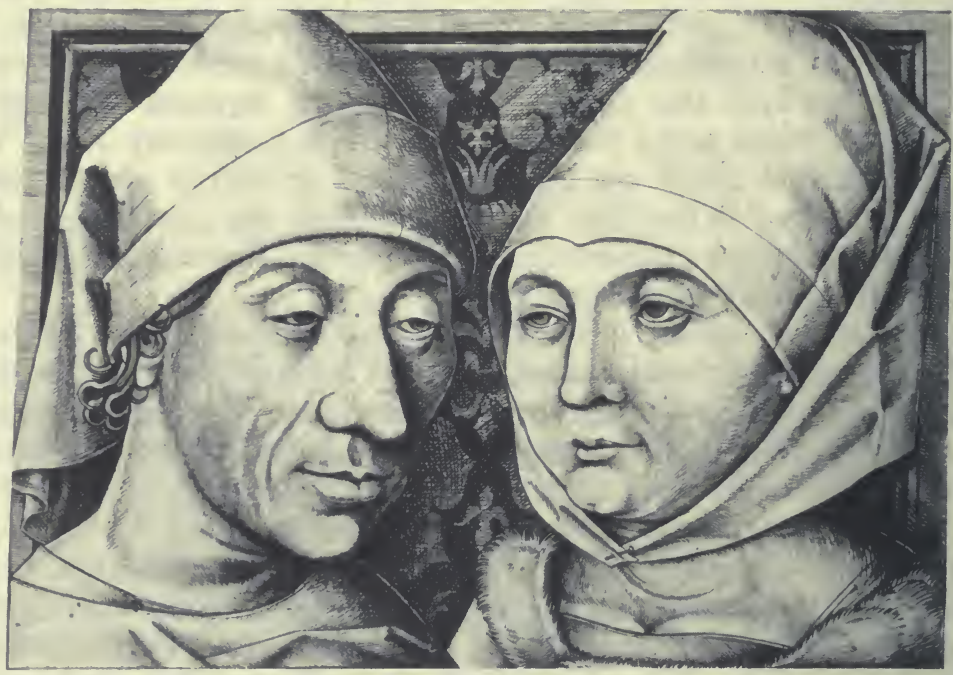

Fig. 6: Israhel van Meckenem, Double Portrait of Israhel van Meckenem and His Wife Ida, engraving, ca. 1490, National Gallery of Art, Washington, D.C.

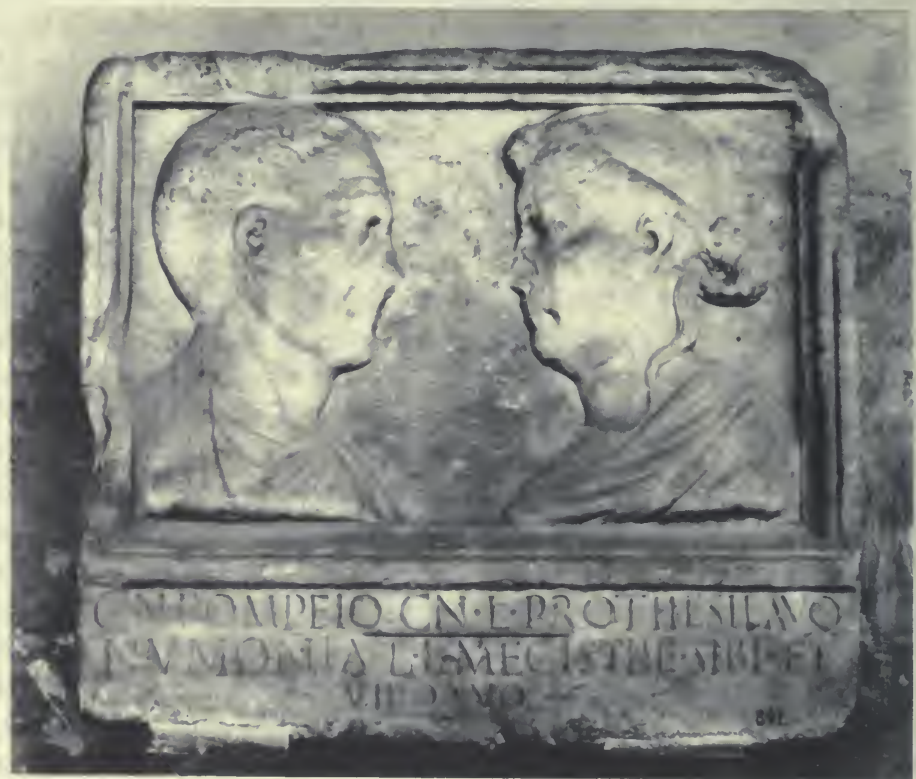

Fig. 7: Roman tomb relief of a Married Couple, c. 13 BC - AD 5, Museo Nazionale delle Terme, Rome 
Renaissance et Réforme / 37

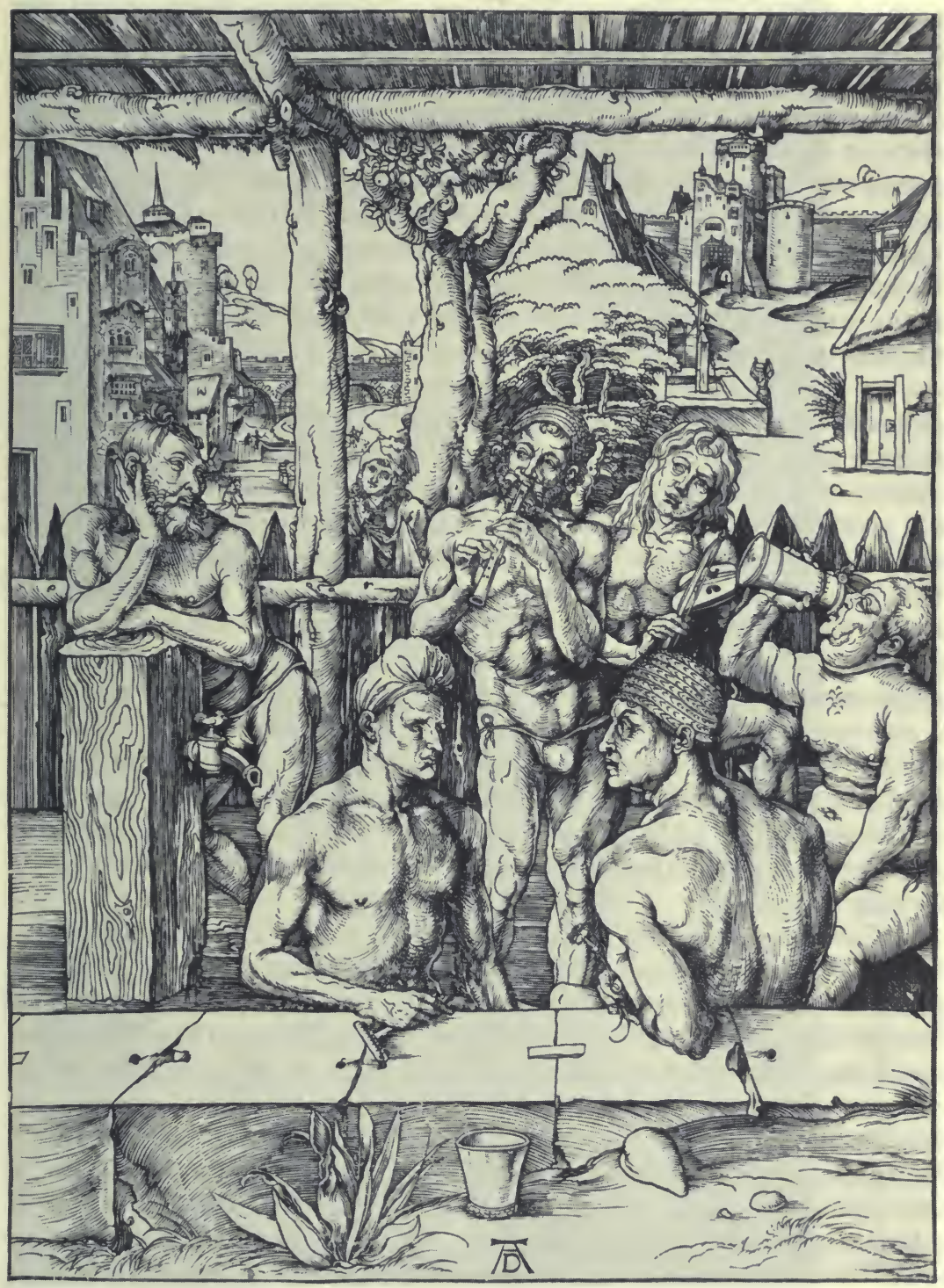

Fig. 8: Albrecht Dürer, The Men's Bath, Woodcut ca. 1497, Metropolitan Museum of Art, New York. 
scenes, some of them conjugal, in which eyes and bodies intertwine. Otto Brendel and others have shown that Titian's Venus imagery plays with the Ficinesque idea of love through the various senses, newly fashionable through the writings of Castiglione and Bembo. ${ }^{56}$ While Otto Brendel sees these paintings moving up a Neoplatonic hierarchy of the senses from hearing to sight, the prevalence of touch in the Berlin Venus and the Organist works against this hierarchical interpretation (fig. 9). To me, especially in light of Titian's Marriage Portrait in the Louvre with its erotic and yet profound touching, ${ }^{57}$ the Venetian painter was less interested in hierarchies of sense than in reconciling opposites, sight and touch, and bringing a new organic wholeness to love's physical expression.

Similar to Titian's mingling of senses is Jan Saenredam's engraved series on the five senses based on designs by Goltzius. ${ }^{58}$ Each sense is explored in terms of love. Touch, recognized by its familiar emblem the biting turtle, seems just as much an image of taste (imminent kissing), smell (flowers), and sight (fig. 10). Though parallels in Netherlandish poetry could probably be discovered, one thinks of similar lines from Shakespeare's Venus and Adonis, which read, 'Look in mine eye-balls, there thy beauty lies: / Then why not lips on lips, since eyes in eyes' (II. 119-20). On the other hand, Goltzius' image of Sight, symbolized by the usual mirror, introduces a conspicuous breast touching, mingling the most spiritual with the most physical kind of union (fig. 11). Like Titian, Goltzius seems less concerned with a Platonic hierarchy of the senses that with overlapping one onto another, each mingling in a synthetic chord of anatomical delight and physical affection. No doubt both artists would have been frustrated by gestures of sight alone: the High Renaissance dramatic aesthetic demanded moving bodies and a love conveyed through intertwined, 'touching' forms.

Our final image is an engraving by Annibale Carracci entitled Reciprocal Love which reproduces a slightly earlier, anonymous Venetian painting now in the Vienna museum (fig. 12). ${ }^{59}$ Because the print's inscription refers specifically to reciprocal love, it is more useful to our argument than the painting. Like Titian and Goltzius, Carraci's print also combines reciprocal gazing and touching in a beautiful harmony amid a 'Golden Age' landscape suited to a pure and noble sensuality. ${ }^{60}$ Roughly contemporary with Annibale's print is the most famous lyric to speak of mutual gazing, a poem which also joins ocular communion with that of the hands, evoking in the latter love's physical dimension as well as the conjugal rite of joined hands. This of course is John Donne's The Extasie, which also situates its lovers in an idyllic garden. 
Renaissance et Réforme / 39

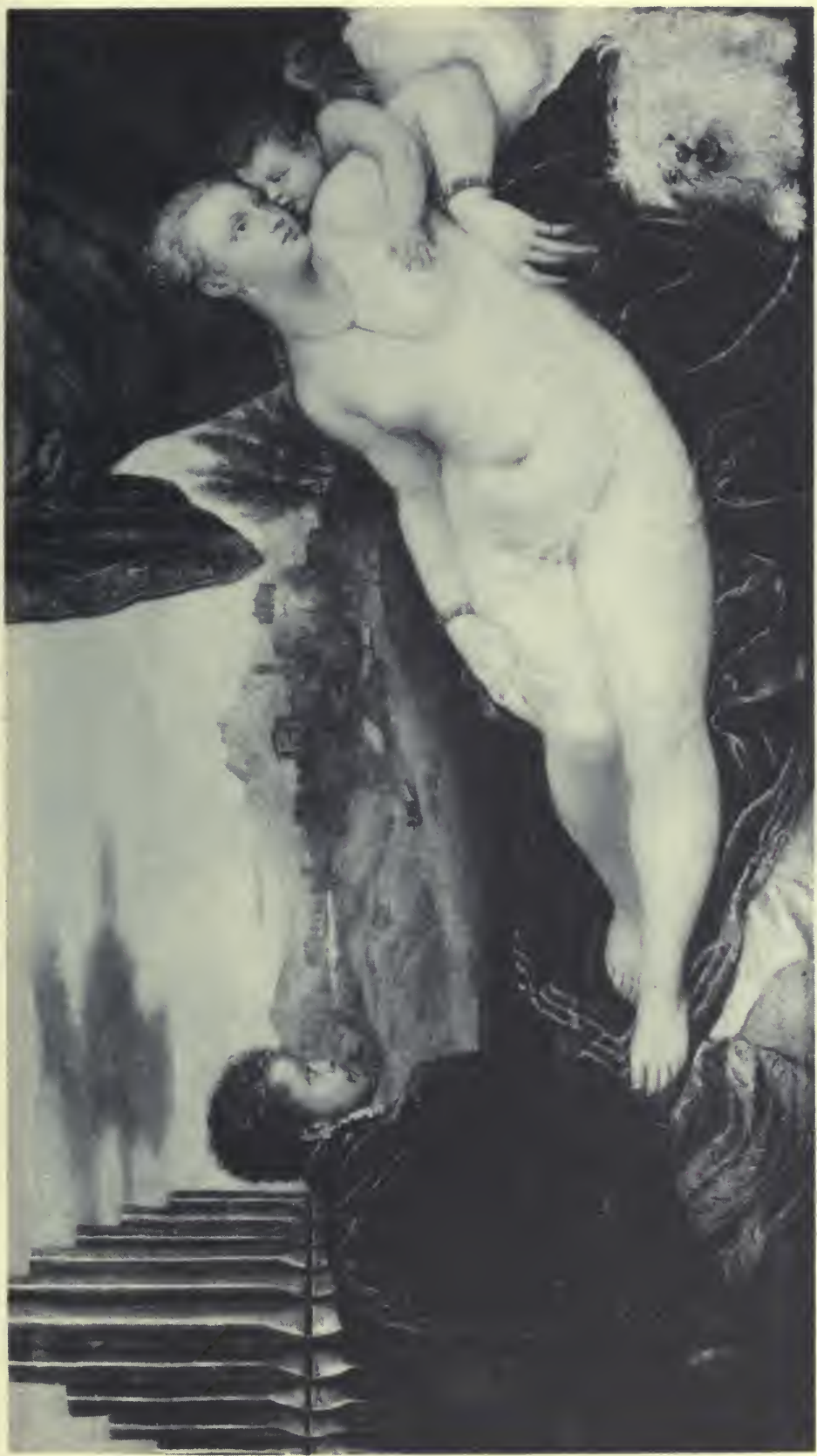

틀 


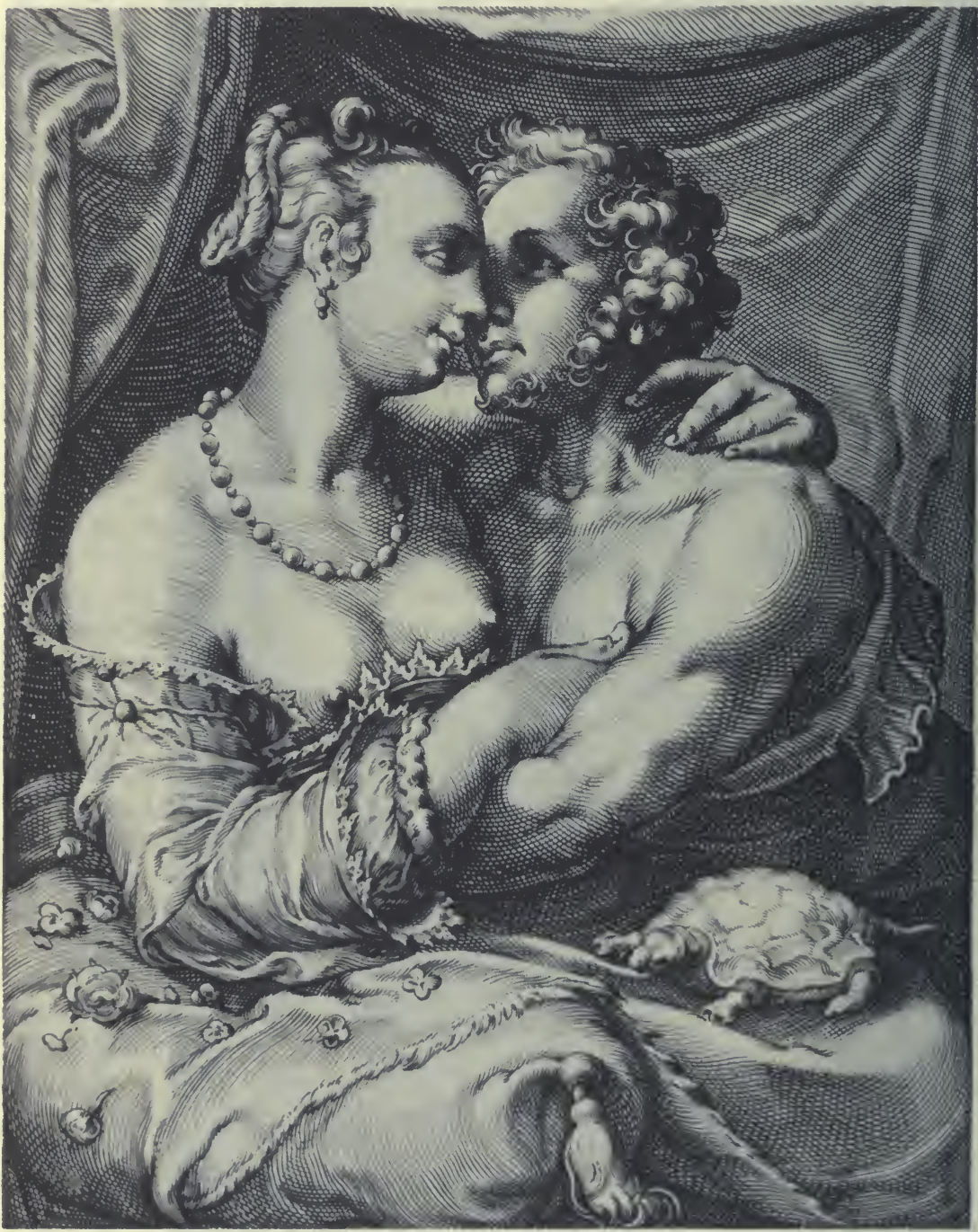

Fig. 10: Jan Saenredam, Touch, engraving B.99 after a design by Hendrik Goltzius, Rijksmuseum, Amsterdam. 
Renaissance et Réforme / 41

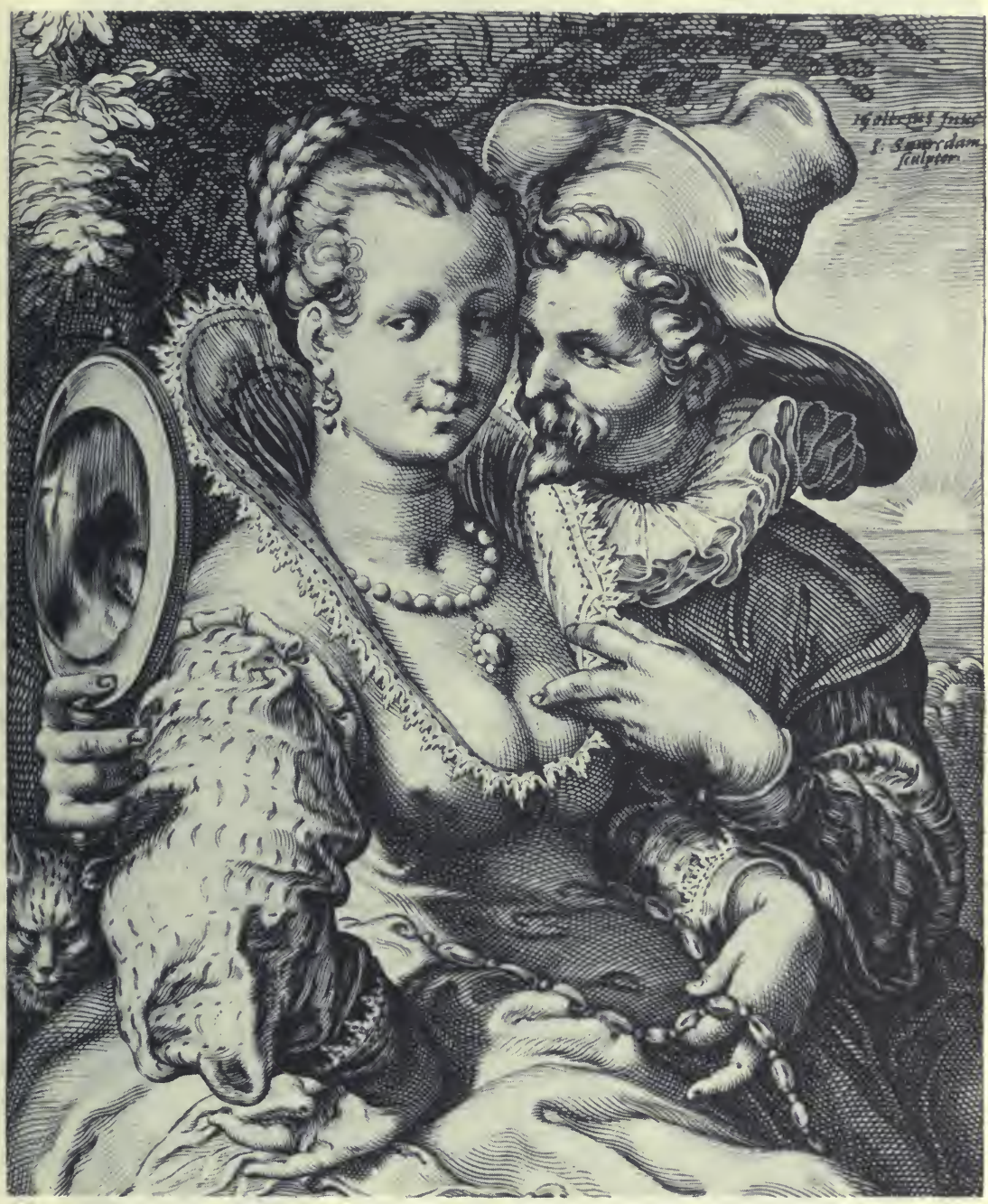

Fig. 11: Jan Saenredam, Sight, engraving B.95 after a design by Hendrik Goltzius, Rijksmuseum, Amsterdam. 


\section{2 / Renaissance and Reformation}

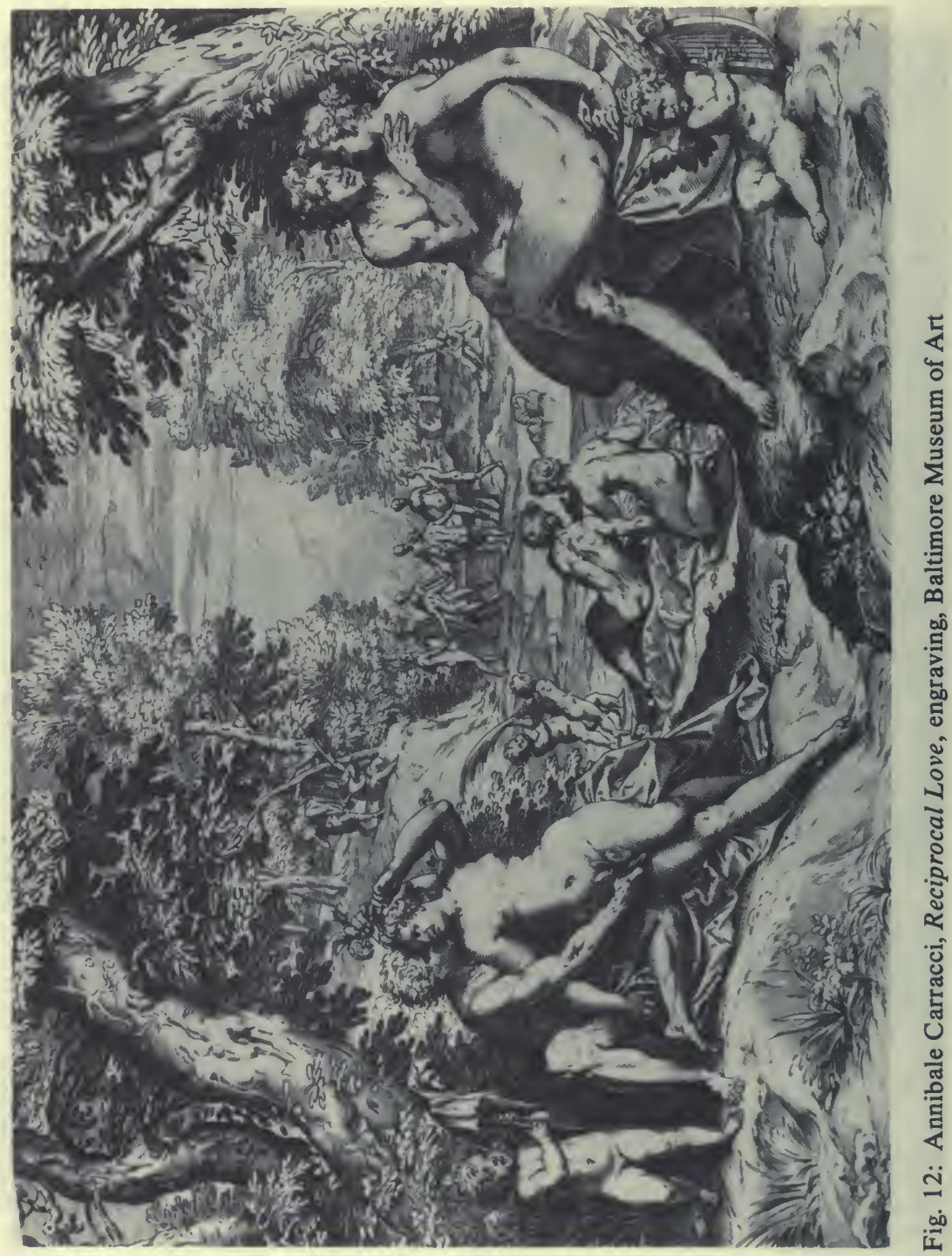


The violet's reclining head,

Sat we two, one another's best.

Our hands were firmly cemented

With a fast balm, which thence did spring;

Our eye-beams twisted, and did thread

Our eyes, upon one double string,

So to intergraft our hands, as yet

Was all the means to make us one,

And pictures in our eyes to get

Was all our propagation.

As, 'twixt two equal armies, Fate

Suspends uncertain victory,

Our souls (which to advance their state,

Were gone out) hung 'twixt her and me

And whilst our souls negotiate there,

We like sepulchral statues lay;

All day, the same our postures were,

And we said nothing all the day. ${ }^{61}$

Here, the sepulchral immobility of forms seems to exclude sexual union in favor of the more spiritual ecstasy of souls meeting through hands and particularly eye-beams which touch. If Donne's poem is the most majestic verbal image of mutual gazing, we have already seen a fairly extensive body of antique and Renaissance works, literary and pictoral, which give this motif vivid and memorable expression. From Fra Filippo's sacramental gazing to the idyllic eroticism of Carracci's Baroque garden and Donne's lyrics, we have a progression from the restrained and austere to the sensual, and yet a progression which maintains the same lofty seriousness of the Lippi. After the Baroque, the sacramental and the sensuous, the sacred and the profane, could never intertwine like Donne's eye-beams, souls meeting though bodies. After the seventeenth century, the motif of mutual gazing would be more sentimental than a mystery of caritas sublimating eros. Watered down to the level of countless modern advertisements, it can be touching in a momentary way, but the Renaissance fusion of eye and spirit, in part dependent on the incorrect optical notion of projecting eye-beams, has become a beautiful thing of the past.

\section{Connecticut College}

\section{Notes}

This article is part of a series of studies on the iconography of sight and touch. As such, it is dedicated to one of the world's authorities on the 'Five Senses' topic, Carl Nordenfalk, Director of the National Museum in Stockholm. Dr Nordenfalk has kindly supplied me with bibliographic material and his own articles have blazed a trail down which I tread. His future book surveying the iconography of the 'Five Senses' in Western art is eagerly awaited. 
1 More than twenty articles and books exist on amorous sight as a literary motif up to the Renaissance. Much of the bibliography can be found in the following. Ruth Cline 'Hearts and Eyes' Romance Philology 25 (Feb. 1972) 263-97; Robert Klein 'Spirito Peregrino' in idem., Form and Meaning. Writings on the Renaissance and Modern Art trans. Madeline Jay and Leon Wieseltier (Princeton 1979) 62-85; Lance K. Donaldson-Evans Love's Fatal Glance: A Study of Eye Imagery in the Poets of the 'Ecole Lyonnaise' (University, Miss. 1980) Though examples of mutual gazing appear in the above literature, the motif is never taken up in its own right.

2 See Cline, Donaldson-Evans, passim.

3 Ibid. Ancient works which seem to play on the mutual gazing motif include a fifth-century cup in Munich of 'Achilles Slaying the Amazon Queen, Penthesilea,' illustrated in John Boardman and Eugenio LaRocca Eros in Greece (Milan-New York 1975) 108-9. Ignoring the literary tradition which tells how Achilles removed the armour from her corpse and then fell in love, the Munich cup shows him falling in love at the moment of her death, their eyes meeting in an intimate and tragic moment. See also Dietrich von Bothmer, Amazons in Greek Art (Oxford 1957) 4, 72, 145. Mutual gazing also appears in a first-century B.C. intaglio of 'Hercules and Omphale' in Vienna (illus. in Boardman, 161); a third-century B.C. Etruscan vase with an unidentified pair of male and female heads. (illus. in Otto Brendel Etruscan Art Harmondsworth-New York 1978, fig. 303); a pair of fourth-century B.C. Etruscan sarcophagi in Boston (illus. in Brendel, figs. 299-300); and an Etruscan mirror of 'Venus and Adonis' (illus. in Eduard Gerhard Etruskische Spiegel Berlin 1840-1897, 5 vols., no. 83). Mutual gazing of a political sort may indicate concord as well in the famous 'Tetrarchs' and in second-century coins showing imperial busts facing each other. For the latter and the early Christian coins of 'Peter and Paul' facing each other in bust, perhaps playing on the spirituality of sight and the concord of souls, see Andre Grabar Christian Iconography (Princeton 1968) 68-70, figs. 163 5. Thanks to Eugene Dwyer for calling these coins to my attention. For Roman conjugal tomb reliefs with mutual gazing see note 51 below, and my fig. 7 .

4 Quoted from Ovid The 'Art of Love' and Other Love Books by Ovid (New York 1959) 7.

5 'Dum nos fata sinunt, oculos satiemus amore: nox tibi longa venit, nec reditura dies,' quoted in Elizabeth Haight Romance in the Latin Elegiac Poets (New York 1932) 107.

6 See Lucretius The Nature of Things Bk. I, lines 32-37, trans. Frank Copley (New York 1977) 1; 'Mars the War Lord... Often throws himself into your arms, faint with love's deathless wound, and there, with arching neck bent back, looks up and sighs, and feeds a lustful eye on you, and pillowed, dangles his life's breath from your lips.' As Gombrich has shown, the description of Mars and Venus in the first canto of Poliziano's Stanze per la giostra draws on Lucretius. See E.H. Gombrich 'Botticelli's Mythologies' idem., Symbolic Images (London 1972) 31-84, esp. 215, n. 133. Poliziano's Cupid 'trovolla assisa in letto fuor del lembo, / Pur mo' di Marte sciolta dalle braccia, / Il qual roverso li giacea nel grembo, / Pascendo gli occhi pur della sua faccia.' (He finds her sitting on the edge of the bed, emerging from the embrace of Mars, who was lying on his back in her lap, feasting his eyes on her face.)

7 A fresco of 'Venus and Adonis' by Guilio Romano (Vatican, Loggie) engraved by Marc Antonio Raimondi (Bartsch, 1484), established the most common grouping for lap-lying lovers, appearing in a painting of 'Lovers' by Garofalo (National Gallery, London) and in Poussin's 'Venus and Adonis' (Look Collection).

8 Quoted in Donaldson-Evans, 17.

9 Donaldson-Evans, 17.

10 Donaldson-Evans, 17.

11 The Greek Romances of Heliodorus, Longus, and .Achilles Tatius trans. R. Smith (London 1855 ) 360-1, cited in Donaldson-Evans, 23-4.

12 Greek Romances, 445, cited in Donaldson-Evans, 24.

13 See Paul Zweig The Heresy of Self-Love (New York 1968) 63-120; Frederick Goldin The Mirror of Narcissus in the Courtly Love Lyric (Ithaca 1967); Jean Frappier 'Variations sur le theme du miroir, de Bernard de Ventadour à Maurice Scève' Cahiers de l'association inter- 
nationales des études françaises 11 (May 1959) 134-58; Guido Favati 'Il tema degli occhi come specchio' Studi in onore di Carlo Pellegrini (Turin 1963) 3-13; John Fleming The Roman de la Rose: A Study in Allegory and Iconography (Princeton 1969), 95-100; Herbert Grabes Speculum, Mirror, und Looking-Glass. Kontinuität und Originalität der Spiegelmetapher in den Buchtiteln des Mittelalter und der englischen Literatur des 13. bis 17. Jahrhunderts (Tübingen 1973) 78-92; Theodor Frings and Elizabeth Lea " "Das Lied vom Spiegel und von Narziss," Morungen, 145, 1, Kraus 7' Beiträge zur Geschichte der deutschen Sprache und Literatur 87 (1965) 40-200; Margaret Freeman The Unicorn Tapestries (New York 1976) 46, 119.

14 Gottfried von Strassburg Tristan und Isolt ed. Friedrich Ranke (Dublin-Zurich 1968) 138 , lines 11,003-5: 'daz da vil lützel ougen was, / in enwaeren diu zwei spiegelglas / ein wunder unde ein wunne'.

15 Gottfried von Strassburg, 147, lines 11,716-27: 'si wurden ein und einvalt, / die zwei und zwivalt waren e; / si zwei enwaren do nieme / widerwertic under in . . . mit liebe also vereinet, / daz ietweder dem anderm was / durchluter alse ein spiegelglas. / si haeten beide ein herze'. Earlier in the romance, Gottfried describes the amorous gazing between Blancheflor and Rivalin: 'They experienced the truth of that saying that where lovers gaze into each other's eyes, they feed love's fire apace" (Ranke ed., 14, lines 1115-8: "ez ergienc in rechte, als man giht: / swa liep in liebes ouge siht, / daz ist der minnen viure / ein wahsendiu stiure').

16 Freeman, 46, 119.

17 For the lovers and monkey, see H.W. Janson Apes and Ape Lore in the Middle Ages and the Renaissance (London 1952) 212-6, 261-3.

18 For the Master E.S. print, see Keith Moxey 'Master E.S. and the Folly of Love' Simiolus 113 / 4 (Fall-Winter 1981) 125-48. Moxey does not discuss the 'eyes as mirrors' conceit.

19 Guido delle Colonne, Historia Destructioni Troiae trans. with an introduction and notes by Mary Elizabeth Meek (Bloomington-London 1974) 71-2 (Bk. 7, lines 237-47).

20 'Summo igitur studio Paris iuxta Helenam, modestie finibus non omissis, fit proprior et dum in eius lumina figit intuitum, Helena intuentis aspectus ex suorum aspectibus mutua relacione repensat ... Sane inspiciendi Paridem aviditate correpta curis tota deprimitur, ad aliud inspectura sua lumina non retorquens. Quam dum Paris percipit sibi suis luminibus blandientem, gaudet suos radios visuales visualibus Helene radiis commisceri, et sic per mutuas et placidas visiones sibi invicem consonantes communis amoris vehementiam manifestant ... ', Guido de Columnis Historia Destructionis Troiae ed. Nathaniel Edward Griffin (Cambridge, Mass. 1936, reprint New York 1970) 73.

21 A good example of medieval amorous sight in general is found in Andreas Capellanus The Art of Courtly Love trans. John Parry (New York 1969) 28-9.

22 Hildegard of Bingen Causae et Curae ed. Kaiser(Leipzig 1903) 72-3: 'Cum mulieribus in honestate et fertilitate esse possunt et se etiam ab eis abstinere valent et pulchris et sobriis oculis eas inspiciunt, quoniam, ubi oculi aliorum ad eas velut sagittae sunt, ibi oculi istorum ad ipsas honeste symphonizant... cited in Peter Dronke Medieval Latin and the Rise of the European Love-Lyric (Oxford 1965) 67-8, n. 1.

23 Helen North From Myth to Icon. Reflections of Greek Ethical Doctrine in Literature and Art (Ithaca 1979).

\section{Louise Vinge The Five Senses. Studies in a Literary Tradition (Lund 1975).}

25 Quoted from Arthurian Romances by Chrétien de Troyes trans. W. Wistar Comfort (LondonNew York, repr., 1975) 127. For the Latin see Christian von Troyes Sämtliche Werke ed. Wendelin Foerster (Halle 1884) 112-13 (Cligés, lines 2800-18): 'Meis Cligés par amor conduit/ Vers li ses iauz covertemant / . . Mout deboneiremant l'esgarde, / Meis de ce ne se prant il garde / Que la pucele a droit li change, / Par buene amor, non par losange, / Ses iauz li baille et prant les suens ... / Meis n'an set plus que bel le voit/ Et s'ele rien amer devoit / Por biauté que an li veîst, / N'est droiz qu'aillors son cuer meîst. / Ses iauz et son cuer i a mis / Et cil li ra le suen promis.' 
26 See Vinge, passim.

27 See the bilingual edition, The Romance of Flamenca (Princeton 1962) 357-9, lines 65716611: 'Quan dui aman fin e coral / Dreigz oilz s'esgaron per egal, / Endreg amor, mon eissient, / Tan granz jois al cor lur deissent / Que li douzor que d'aqui nais / Lur reven tot lor cor e pais. / E l'ueil, per on treva e passa / Cil douzors ques el cor s'amassa, / Son tan lial que nulla ren / Negus a sos ops non reten. / Mais la boca nos pot tener, / Quan baisa, que del bon saber / A sos obs quesacom nom prenga / Avan que ren al cor ne venga ... Mais cil autre que baizar podon / A lur guisas, e puissas rodon, / Ades entorn per las faissolas, / Non s'asauton d'aitals esgolas. / Mais tals n'i a cui non conven / Lo joi d'amors que d'ueilz lur ven / Neguna sason oblidar, / Ni per tener ni per baisar, / Quar ren non sabon neis ques es, / Mais tan con Rasons e Merces / E Consiena lur ensegna / Que baisars es vera antressegna / Del joi que fin' Amors aporta / Per oilz, per cui ha faita porta / Clara e pura e lusen.'

28 See Jean Leclercq Monks on Marriage: A Twelfth-Century View (New York 1982) for the spiritual emphasis in medieval marriage, and pp. 44-48 for virgin marriages. The legend of Cecilia and Valerian is recounted in the Golden Legend.

29 Vinge 71-3 et passim. For love and the five senses see Charles Dahlberg 'Love and the "Roman de la Rose' "Speculum 44 (1969) 568-84, esp. 575-8; L.J. Friedman 'Gradus Amoris' Romance Philology 19 (1965) 167-77; A. Adler 'The Topos "Quinque Linea Amoris Sunt Amoris" Used by Ronsard in "Amours" "Bibliographie d'Humanisme et Renaissance 15 (1953) 220-2.

30 Marsilio Ficino Commentary on Plato's Symposium trans. S.R. Jayne, University of Missouri Studies 19.11944 (Columbia, Mo. 1944) 146. The Latin reads: 'Accedit quod amans amati figuram suo sculpit in animo. Fit itaque amatis animus speculum: in quo amati relucet imago.' See Marsilio Ficino Opera (Basel 1561) 1328.

31 Baldassare Castiglione The Book of the Courtier (London 1959) 247. For the Italian see Il Cortegiano ed. Vittorio Cian (Firenze 1894) 339: 'gli occhi saettano, ed affatturano come venefici; e massimamente quando per dritta linea mandano i raggi suoi negli occhi della cosa amata in tempo che essi facciano il medesimo; perché i spiriti s'incontrano, ed in quel dolce intoppo l'un piglia le qualità dell'altro ...'

32 Giordano Bruno Candelaio I.x: 'L'esser fascinato d'amore adviene, quando con frequentissimo over, benché istantaneo, intenso sguardo, un occhio con l'altro, e reciprocamente un raggio visual con l'altro si riscontra, e lume con lume si accopula. Allora si gionge spirito a spirito; ed il lume superiore, inculcando l'inferiore, vangono a scintillar per gli occhi, correndo e penetrando al spirito interno che sta radic ato al cuore; e cossi commuoveno amatorio incendio.' (Fascination by love takes place when owing to very frequent looking or to an intense, though instantaneous, look, one eye meets another, and two eye-beams reciprocally encounter, and light couples together with light. Then spirit joins with spirit; and the superior light informing the inferior one, they come to sparkle through the eyes, rushing to, and penetrating, the inner spirit which is rooted in the heart; and this manner they kindle erotic fire.) Bruno's text was first suggested by Mario Praz 'Donne's Relation to the Poetry of His Time' idem., The Flaming Heart (New York 1973) 186-203, esp. 197-8. Also see John Arthos, 'Letter to the Editor' Review of English Studies 21 (Feb. 1970) 163.

33 See Lisle Cecil John The Elizabethan Sonnet Sequences (New York 1938) 124-6; Virgil Jackson Lee 'Conceits of Love Through the Eyes' idem. The Face in Shakespeare: A Study of Facial Gesture and Attitude as Aspects of Dramatic 'Energeia' (Ph.D., Columbia University 1969) 108-17; Zweig, 100-8; Grabes, 78-92.

34 The literature on The Extasie is large. See Charles Mitchell 'Donne's “The Extasie": Love's Sublime Knot' Studies in English Literature: 1400-1900 8 (1968) 91-101.

35 John Pope-Hennessy and Keith Christiansen 'Secular Painting in Fifteenth-Century Tuscany' Metropolitan Museum Bulletin 38.1 (1980) esp. 56-9. The authors point out that the man was intended from the start, and judging from his coat of artms, seems to be a member of the Scolari family, perhaps Lorenzo Scolari. The picture seems to be from the 1440 s, so that it is probably not an engagement picture, Lorenzo being married in 1436 . 
36 Das Kunstwerk des Monats Ulmer Museum (June 1982).

37 Carla Gottlieb 'The Window in the Eye and Globe' Art Bulletin 57.4 (1975) 559-60; idem. The Window in Art (New York 1981) 163-71; Vinge, 21-39.

38 For other Canticles imagery in Lippi, see Marilyn Aronberg Lavin 'The Joy of the Bridegroom's Friend: Smiling Faces in Fra Filippo Lippi, Raphael, and Leonardo' in Moshe Barasch and Lucy Freeman Sandler eds. Art The Ape of Nature (New York 1981) 193-210. Lippi's Uffizi 'Virgin' has even more Canticles imagery in it than Ms Lavin describes. The complex rocks in the landscape behind draw on Canticles 2:14, one of the most common motifs in Passion devotions. See John Morson Christ the Way. The Christology of Gueric of Igny (Kalamazoo 1975) 129-36; and D.W. Robertson Jr "In Foraminibus Petrae": A Note on Leonardo's "Virgin of the Rocks" 'Renaissance News 7 (1954) 92-5. A forthcoming study by Frederick Hartt will also show a nuptial meaning for the large pearl on the forehead of Lippi's 'Uffizi Madonna'.

39 L. Delaissé and James Marrow Illuminated Manuscripts: The James A. de Rothchild Collection at Waddesdon Manor (Fribourg 1977) 81, pl. 17, (Book of Hours of Guillebert de Lannoy, Netherlandish, ca. 1430); and Iluminated Books of the Middle Ages and Renaissance, exhib. cat., Walters Art Gallery (Baltimore 1969) fig. 88 (French Book of Hours, ca. 1425).

40 La Bible moralisée illustrée, conservée à Oxford, Paris et Londres (Paris 1911-27) 5 vols., pl. 305.

41 The Marten de Vos is discussed in Gottlieb, 278, fig. 153.

42 Gilbert of Hoyland Sermons on the Song of Songs trans. Lawrence C. Braceland, 3 vols. (Kalamazoo 1978-9) 2:363 (Sermon 30.2). For the Latin, see Sermones in Cantica (P.L. 184.155-6): 'Ne parcas, sponsa talibus Sponsum telis appetere. Aspectibus piis quasi spiculis utere... sed concide ipsum vulnere super vulnus. Felix es si sagittae tuae infixae sunt illi, ... si oculus tuus defixus indefesse sit in illo... Ideo puri aspectus in illum spicula vibra ... Mala enim sanitas, ubi vulnera vacant quae Christi pius infligit aspectus. Aspectus aspectum provocat: ideo tuo illum tenta vulnerare prospectu. Oculi tui semper ad Dominum, ut amoris tui nutibus capiatur, illaqueetur criniculis.'

43 John of Ford Sermons on the Final Verses of the Song of Songs trans. Wendy Mary Beckett, 5 vols. (Kalamazoo 1977-83) 2:18 (Sermon 16.2). Similar texts can be found in 1:134, 3:86, 4:28, 5:18 and 5:157-8. The Latin reads: 'quos ad uidendam Dei maiestatem, Dei sapientiam, Deique benignitatem non multis niti gradibus et laboriosis se immiscere quaestionibus oportuit, sed magis dilectum suum stantem post parietem nostrum et per fenestras sensuum nostrorum prospicientem ad eos mox uicissim respicere, et unius tantum obtectu parietis et uno solum gradu ab aeternae lucis ineffabili illa, quae in coelis est.' See Ioannis de Forda Super Extremam Partem Cantici Canticorum Sermones $C X X$ ed. Edmund Mikkers and Hilary Costello, Corpus Christianorum, Continuatio Mediaevalis 17, 2 vols (Turnholt 1970) 1:142.

44 Gertrud Schiller Ikonographie der christliche Kunst (Gütersloh 1976) 4.1:102-3.

45 Nicolas of Cusa The Vision of God trans. Emma Gurney Salter (New York 1960) 17. The Latin reads: 'quando solum ad te attentissime respicio et nunquam oculos mentis auerto, quia tu me continua visione amplecteris.' See Nikolaus von Kues Werke ed. Paul Wilpert, 2 vols. (Berlin 1967) 1:297.

46 Nicolas of Cusa Vision of God, 23; Werke 1:299: 'Quanto ego domine deus meus diutius intueor vultum tuum, tanto mihi apparet quod acutius in me iniicias aciem oculorum tuorum.'

47 Millard Meiss 'The Problem of Francesco Traini' Art Bulletin 15 (1933) 97-173, esp. 121-2, figs., 21-2. For the evil eye and amulet, see S.A. Callisen 'The Evil Eye in Italian Art' Art Bulletin 19 (1937) 450-62. Donatello's 'Pazzi Madonna' in Berlin is another excellent example of mutual gazing between Virgin and Child. Mutual gazing between Christ and the soul is featured in Parmigianino's 'Mystic Marriage of St Catherine'.

48 The faithful eye, looking only at Christ, appears frequently in late medieval devotional literature. See for example, Henry Suso The Little Book of Eternal Wisdom, and, Little Book of Truth trans. James Walsh (London n.d.) 102, 122, 135. 
49 John of Ford, 5:157-8 (Sermon 75, 3-4).

50 See my article 'Marriage as a Sacramental Reflection of Christ's Passion: The Mirror in Jan van Eyck's "Arnolfini Wedding”' Oud Holland 98.2 (1984) 57-75.

51 Sixten Ringbom 'Nuptial Symbolism in Some Fifteenth-Century Reflections of Roman Sepulchral Portraiture' Temenos 2 (1966) 73-97. See Diane Kleiner Roman Group Portraiture Garland Press (New York 1977) 24-5, fig. 24, for three Roman tomb reliefs with profile, mutual gazing. Thanks to Dr Kleiner for help in obtaining my fig. 7. For Jacopo Bellini's drawing of such antiquities, frequently doubted by art historians unfamiliar with the Roman examples, see Fritz Saxl $A$ Heritage of Images (London 1970) fig. 81.

52 Edgar Wind proposes an elaborate, allegorical reading of the woodcut based on Dionysian rites of purification, a theory refuted by Panofsky. In addition, Wind sees four of the main figures as portraits of Dürer and his friends, each personifying one of the four temperaments. The portrait idea is not born up by physiognomic resemblance; the fat beer drinker seen by Wind as Pirckheimer is much closer to a Silenus figure from Mantegna as Tietze has pointed out. The four temperaments in a bathhouse is unprecedented, and seems to be more a construct of Wind's humanism than Dürer's. See E. Wind 'Dürer's Mannerbad: A Dionysian Mystery' Journal of the Warburg and Courtauld Institutes 2 (1938-9) 269-71. More information and references on the print are found in Albrecht Dürer: Woodcuts and Wookblocks ed. Walter L. Strauss (New York 1980) 126-8.

53 I owe the identification of the amator exclusus type to Eugene Dwyer who also referred me to Wind's article.

54 Walter Gibson Hieronymous Bosch (New York 1973) fig. 25.

55 Kleiner, 24-5.

56 Otto Brendel 'The Interpretation of the Holkham Venus' Art Bulletin 28 (1946) 65-75; Vinge, passim; see also Ulrich Middeldorf 'Letter to the Editor' Art Bulletin 29 (1947) 65-6.

57 Erwin Panofsky Studies in Titian. Mostly Iconographic (New York 1969) 126-7.

58 The mirror in 'Sight' also draws on an amatory tradition explored in Elise Goodman-Soellner 'Poetic Interpretations of the "Lady at her Toilette" Theme in Sixteenth-Century Painting' Sixteenth-Century Journal 14.4 (1983) 426-42.

59 Diane DeGrazia Bohlin Prints and Related Drawings by the Carracci Family (Washington, D.C. 1979) no. 191; Otto Kurz, 'Four Forgotten Paintings by Agostino Carracci' Journal of the Warburg and Courtauld Institutes 14 3/4 (1951) 221-33.

60 The love making celebrated in Carracci's engraving is similar to that in Marino's somewhat later poem, $L$ 'Adone. There, the five senses play a key role, especially touch, which is now seen in a positive way. See Vinge, 113-17.

61 See the discussion and literature in Mitchell, op. cit., passim. 